\title{
Larvæ of Decapod Crustacea*
}

$\mathrm{T}^{\mathrm{H}}$ HE first contribution to the study of the decapod larvæ of the "Discovery" expedition deals with the Stenopidea, Amphionidx and Phyllosoma. The whole collection is so large that the easiest and best way to treat it is by taking the groups separately irrespective of systematic order. The three sections chosen are of peculiar interest, and their elucidation has entailed an enormous amount of labour, eminently worth while.

Most of the plankton samples were taken far out to sea, and one of the features of the collection is the abundance of late larvæ, whilst early larvæ are comparatively scarce. For this reason, it is rarely possible to complete a life-history of any form. In Part 1, Stenopidea, the author was fortunate in obtaining larvæ hatched from the egg of Stenopus hispidus from Bermuda (previously somewhat inadequately described by Brooks and Herrick), which has enabled him to recognize later larvæ and to establish certain generic characters. Two further species (presumably) of Stenopus are described and six more belonging to the Stenopidea, and a key is given to the stenopid larvæ described.

Part 2, on the Amphionidæ, is of special interest, for Amphion is a form which has led to much controversy both as to its systematic position and as to whether it is a larval or adult animal. There can be now no doubt that the oldest specimens known are immature, and Dr. Gurney is almost certainly right in referring Amphion to the Caridea (as Korscheldt and Heider had previously suggested). Given that it is a carid, then he believes that the only known genus to which it can be referred is Amphionides, three specimens of which were found in the "Discovery" material, from a depth of 2,500-2,700 metres. This most extraordinary decapod is so tender that in all instances known it is much damaged; but a construction of one of them certainly shows a distinct likeness to Amphion. Zimmer, who first described Amphionides, regarded it as a larva and observed that it closely resembles Amphion. Dr. Gurney remarks that he might have gone further and claimed it as an adolescent post-larval stage in the development of that crustacean, for, as he shows, Amphionides is certainly a post-larval form. All this is most interesting and suggestive.

Part 3 deals with the Phyllosomas, and here the work is remarkable, for no fewer than four hundred specimens have been examined and measured, and about a dozen forms recognized. No series, unfortunately, is complete, and no very early stages are present. Nevertheless, generic larval characters are described which distinguish Palinurus, Panulirus, Jasus, Scyllarus and Scyllarides and, probably, Palinurellus, Thenus and Parribacus. A very large amount of information is given in connexion with these Phyllosomas which will help enormously in future work.

This first section of the expedition's decapod larvæ promises well for future parts.

* Discovery Reports, vol. 12, pp. 377-440. Issued by the Discovery Committee, Colonial Office, London, on behalf of the Government the Dependencies of the Falkland islands. Larvæ of Decapod Crustacea. (1) Stenopidea. (2) Amphionidæ. (3) Phyllosoma crusRobert Gurney. (Cambridge: At the University Press, 1936.)

\section{Forestry in Great Britain}

$\mathrm{T}^{\mathrm{H}}$ HE progress of the afforestation work being carried out by the Forestry Commission in Great Britain for the year ending September 30, 1935 , is detailed in the sixteenth annual report (London : H.M. Stationery Office, 1936). During the year, the programme of work was that laid down by Government at the time of the financial crisis of 1931. In January 1935, the Commissioners reported to Government that it was desirable to review the position generally and to extend the current fiveyear programme, so that the work might be organized to the best advantage.

The Commissioners consider that a steady development is preferable to a sudden large increase of work which might lead to waste. They suggested therefore: (1) that the acquisition of land and the supply of plants should be speeded up ; (2) to work up the annual planting programme from 21,000 acres to 30,000 acres over the next four years ; (3) to continue expanding the programme up to 45,000 acres per annum. Of interest are the remarks made upon Jubilee forests, unemployment training camps, national forest parks and home timber trade.

With the permission of the late King George V, three forests have received Royal designations to commemorate the jubilee, namely, the King's Forest in Suffolk, the Coed-y-Brenin (the King's Forest) in Wales, and the Queen's Forest in the Cairngorms.

In co-operation with the Ministry of Labour, sites of training camps and work such as road-making, etc. have been provided. During the year there were in all thirteen permanent camps and fifteen summer camps, with accommodation for 5,000 men. The camps were distributed at different centres throughout Great Britain.

The question of the formation of national parks has been under consideration by various bodies and individuals for some years past. The Commissioners appointed a committee, under the chairmanship of Sir John Stirling-Maxwell, to consider a specific example. The Commissioners have already, as a result of their land purchases, a considerable area of unplantable land. The Committee took a Scottish example consisting of unplantable land in the Forests of Ardgartan, Glenfinart, Benmore and Glenbranter in the County of Argyll. This area, including the adjacent Ardgoil Estate belonging to the Glasgow Corporation which the Corporation is willing to 